\title{
Serum CA19-9 Equal or Less than 180 Units/ml
}

National Cancer Institute

\section{Source}

National Cancer Institute. Serum CA19-9 Equal or Less than 180 Units/ml. NCI Thesaurus.

Code C84332.

A laboratory test result indicating the presence of a CA19-9 level in the serum which is equal or less than 180 units per $\mathrm{ml}$. 